\title{
Situation of State Management of Private Enterprises in the Market Economy in Vietnam
}

\author{
Pham Van Hieu \\ Hanoi University of Business and Technology, Vietnam \\ E-mail: dangthaibinh1985@gmail.com
}

Received: June 16, 2020 Accepted: September 26, 2020 Published: November 15, 2020

doi:10.5296/bmh.v8i2.17944 URL: http://dx.doi.org/10.5296/bmh.v8i2.17944

\begin{abstract}
Private enterprises play an important role in the economic development of many countries in the world, including Vietnam. In particular, the state management of private enterprises in Vietnam plays an important role in the development of private enterprises in three aspects: promoting private enterprise development; ensure a fair and healthy competitive environment; state manages private enterprises according to the market principle. The state management of private enterprises in Vietnam is of special interest to the Government, which is reflected in the policies, laws, institutions, and support for the development of private enterprises. Analysis of the state management of private enterprises in the market economy in Vietnam helps assess the effectiveness of management measures while pointing out the limitations that need to be overcome so that the state management in this field will be more effective.
\end{abstract}

Keywords: management of the state, private enterprise, market economy 


\section{Introduction}

The private sector plays an important role in Vietnam's economic development, reflected in the number of businesses, its contribution to the country's GDP, and the number of jobs it creates. The contribution from the private sector to GDP has continuously increased over the years from $11.71 \%$ in 2011 to $13.12 \%$ in 2015 . The income tax of high-income earners increased from 5.33\% in 2011 to 5.63\% in 2015 (General Statistics Office of Vietnam, 2016). "The role of non-state economic (excluding foreign investment) has been increasingly promoted, contributing $38.5 \%$ of total social investment and $48.3 \%$ of GDP", "Domestic private investment continued to increase, accounting for about $38.5 \%$ of total social investment" (Party Central Office, 2016). The number of newly established businesses increased rapidly year by year, only in the period 2000-2017 there were about 1 million newly established businesses. The private sector contributes about $40 \%$ of GDP, which is the region with the highest share of contribution to the economy. The private sector creates jobs for about $85 \%$ of the country's labor force, of which the business sector creates about 1-1.5 million new jobs annually. The proportion of investment in the private sector in total social investment has continuously increased, from $22.9 \%$ in 2000 to $38 \%$ in 2005 and $38.7 \%$ in 2015 . The capacity and operation efficiency of the private sector has significantly improved, contributing to the effective use of resources for the country's economic development.

Besides the results achieved, the private enterprise also faces several issues, which requires managers to be mindful of the design of mechanisms and policies to promote private enterprise development efficiency sustainable, and profitable. In the context of globalization, industrialization and modernization, international economic integration, and increasingly fierce competition in the market, the requirements on state management of private enterprises become more important. State management of private enterprises plays a role in protecting and promoting the development of private enterprises; ensure a fair and healthy competitive environment; ensuring compliance with the principles of the market economy, making a common contribution to the economic development of the country.

\section{The Situation of State Management of Private Enterprises in the Market Economy in Vietnam}

State management of private enterprises in a market economy is a way of using economic, administrative, information, and propaganda tools to influence the behavior of private enterprises to guide the private enterprises to achieve the objectives of the country.

\subsection{State Views on Private Enterprise Development Management}

In 2002, at the 5th Conference of the Central Committee of the Communist Party of Vietnam Session IX, the Central Executive Committee issued Resolution No. 14-NQ/TW on continuing to renovate mechanisms, policies, encouraging, and creating favorable conditions to developing private economic in Vietnam. Resolution 14 outlined a unified view of directing the development of the private economy, which identifies the main points of management of private enterprises as follows:

- The private economy is an important constituent part of the national economy. Private 
economic development is a long-term strategic issue in the development of a socialist-oriented market economy. Make an important contribution to the successful implementation of economic development, industrialization, modernization, and improvement of the country's internal resources in the context of international economic integration.

- The State respects and ensures the right to business freedom by the law, protects the legal property rights of citizens, encourages, supports, creates favorable conditions, and guides and manages the development of the private economy by the law, equality among economic sectors.

- Individual business households in both rural and urban areas are facilitated and supported by the State for development; The State encourages households to join forces to form voluntary cooperative organizations, to serve as satellites for businesses, or to a larger development.

- Building a favorable business environment in terms of policies, legal and psychosocial so that private enterprises can develop widely in production and business industries that are not prohibited by law, nor restricted in terms of scale and priority orientations of the State. Encourage to turn into joint-stock enterprises, sell shares to employees, joint ventures with each other, or with the collective economy and the state economy.

- Protection of the legal and legitimate interests of employees and employers. Build good relationships between employers and employees based on law, solidarity. To foster and educate business owners to raise patriotism, national pride, to stick with the interests of the country, and to build socialism. Strengthen the Party's leadership; promote the role of socio-political organizations and business associations in the private economy.

\subsection{Mission}

Resolution 14 of the Party in 2002 also provides the tasks that need to be performed, can summarize the following tasks:

Firstly, unify the point of directing private economic development, considering the private economy as an important constituent part of the national economy. Create a favorable business environment in terms of policies, laws, and social psychology for private enterprises to develop widely in production and business industries that are not prohibited by law or are not restricted in size, especially is according to the priority orientation of the State. Encourage transformation into joint-stock companies, selling shares to employees, joint ventures, linkages, collective economy, and state economy.

Secondly, create an institutional and psychosocial favorable environment for the development of the private economy. Amending and supplementing the Enterprise Law and several inconsistent regulations among the issued legal documents on issues related to the private economy in the direction of eliminating discrimination between economic sectors, ensuring the consistent expression of the Party's views on private economic development. Remove difficulties and problems in the law and administrative procedures. Disseminate and 
propagate the Party and State's views, guidelines, and policies towards the development of the private economy.

Third, amend and supplement several mechanisms and policies. Concentrating on amending and supplementing several mechanisms and policies, ensuring equality between economic sectors in terms of opportunities and the ability to select conditions for development and removing difficulties and obstacles, support small and medium enterprises. Among the mechanisms, policies are amended, supplemented, focus on land policy; financial and credit policies; labor policies - wages; supporting policies on training, science, and technology; supporting policies on information, trade promotion.

Fourth, continue to improve and strengthen state management. Develop and complete the legal framework and issue policies and management mechanisms to production and business units. Law enforcement agencies shall only conduct inspection and examination when private enterprises show signs of law violations.

Fifth, strengthen the leadership of the Party; promote the role of the Vietnam Fatherland Front, unions, and business associations in private economic development.

\subsection{Laws, Institutions, and Policies Governing Private Enterprises}

State management of private enterprises in Vietnam is concretized by laws and policies to manage and promote the development of private enterprises. Particularly, the Law on Private Enterprises, the Companies Law (1990), the Law on Domestic Investment Promotion (1994), the Enterprise Law (1999, 2005), the Investment Law (2005), etc.

- $\quad$ The Law on Private Enterprises and Companies Law (1990)

On December 21, 1990, at the Eighth Session, the Vietnam National Assembly passed two laws on private enterprises: The Companies Law and the Private Enterprise Law. These two Laws were born to show the concretization of policies of the Party and the State, formally acknowledging the legal status of the private sector, promoting the effective mobilization and use of resources: capital, labor, and resources of the country. The Companies Law (1990) has contributed to promoting the effective mobilization and use of the country's capital, labor, and resources, creating more jobs, protecting legal assets and interests of capital contributors, speeding up economic development.

The Companies Law and the Private Enterprise Law (1990) made a strong breakthrough for the development of the private economy and achieved encouraging achievements. In the years 1986-1990, the average annual growth rate of the non-state sector was $6.2 \%$, while that of the state sector was only $1.9 \%$. By 1990 , the share of the state economy was $31.8 \%$, the non-state share was 64.6\%, and foreign investment was 3.6\% (Dao Xuan Sam \& Vu Quoc Tuan, 2008). Since the implementation of the two laws until 1996, a total of about 21,000 private enterprises, 8,900 limited companies, and 190 joint-stock companies have been established. The number of household businesses also increased from 0.84 million in 1990 to 2.2 million in early 1996 (Dao Xuan Sam \& Vu Quoc Tuan, 2008).

- Law on Promotion of Domestic Investment (1994) 


\section{MInstitute Macrothink $^{\text {Int }}$}

Business and Management Horizons

ISSN 2326-0297

2020, Vol. 8, No. 2

The Law on Promotion of Domestic Investment has created more favorable conditions for all economic sectors, to mobilize and use effectively all sources of capital, natural resources, labor to contribute to economic and social development. Article 6 of the Law clearly states that the investors' property, investment capital, and profits are not nationalized. In cases where it is necessary for national reasons of defense and security, the State decides to solicit or requisition properties of investors, the investors shall be paid or compensated according to the market price. Article 6 of the Amending Law also provides extremely favorable factors for private economic development such as the guarantee of investment support, recognition of the protection of property ownership, investment capital, and revenue, investor's legal rights and benefits.

After the amended Law on Promotion of Domestic Investment, a series of Government's Decrees have been issued to create a legal corridor for the economy, including a developed private economy like Decree No. 50/ND-CP. 1998 of the Government on the organization and operation of the Development Assistance Fund; Decree No. 52/ND-CP of 1999 on Promulgating the regulations on investment and construction management; Decree No. 119/ND-CP of 1999 On a number of financial policies and mechanisms encouraging enterprises to invest in scientific and technological activities.

\section{- Enterprises Law 1999, 2005}

On June 12, 1999, the President signed the decision to promulgate the Enterprise Law to take effect from January 1, 2000, marking an important step in forming the legal framework for operations of various types of private businesses. The law gives more autonomy to businesses, thereby helping private enterprises operate more effectively in capitalizing production and business.

The 2005 Enterprise Law replaces the 1999 Enterprise Law, which was passed by the National Assembly in November 2005 and takes effect from July 1, 2006. The 2005 Enterprise Law inherited the success of the 1999 Enterprise Law and added many new elements. (1) Create a common legal corridor for all types of businesses of all economic sectors, not just for the private sector, such as the 1999 Enterprise Law; (2) Adding the type of single-member limited liability company as an individual and allowing the individual to establish a limited liability company; (3) Completing the regulations on corporate governance related to the rights of shareholders, especially minority shareholders, strengthening the regime of information disclosure and transparency.

- Investment Law 2005

The 2005 Investment Law replaced the 1996 Law on Foreign Investment in Vietnam, the Law Amending and Supplementing a Number of Articles of the 2000 Law on Foreign Investment and the 1998 Law on Promotion Domestic Investment. A new feature of the 2005 Investment Law allows private investors to expand their operations further, thereby creating an open environment for investment activities in private enterprises.

- Law on Investment and Law on Enterprises 2014 
Enterprise Law 2014 has expanded its rights and obligations, thereby creating conditions for private enterprises to develop. The 2014 Investment Law replaced the 2005 Investment Law with many important changes, especially the provisions on the ban on investment, conditional investment, and administrative reforms on investment. These are important factors that enable investors (especially individual investors) to facilitate business activities and invest in different sectors of the economy.

The law has completed the current provisions of the Investment Law regarding investment incentive industries and trades as well as the principles and conditions for applying incentives to ensure selective and quality investment attraction. Focusing on industries using high technology, modern techniques, large-scale production projects, labor-intensive investment projects in rural areas, projects for manufacturing supporting industrial products, projects implemented in the fields of investment socialization (health, education, vocational training, culture ...).

\section{- $\quad$ Law on Support for Small- and Medium-Sized Enterprises 2017}

The Law on Supporting Small and Medium-sized Enterprises (SMEs) targets the majority of Vietnamese businesses because over $90 \%$ of Vietnamese businesses belong to the group of SMEs, directly creating jobs for many workers. However, this group of businesses is very weak, low competitiveness, lack of cohesion, lack of ability to participate in the value chain of large enterprises. The law support for SMEs in accessing credit; tax; production ground; technology; information; human resource development. Besides, the law also supports business incubators, technical facilities, common working areas; market expansion; and legal assistance. Supporting small and medium-sized enterprises transforming from business households; assisting small and medium-sized businesses in starting their businesses; investing in small and medium-sized start-up businesses; assisting small and medium-sized enterprises in joining industry clusters and value chains.

Through the above analysis, it can be seen that the legal corridor is increasingly expanding towards creating a favorable business environment for the development of private enterprises. Through the loosening of conditions, loosening the bottlenecks hindering the development of private enterprises, the economic sector has developed strongly. Thereby promoting the role of private enterprises in the market economy with the orientation and management of the State.

\section{Issues in State Management of Private Enterprises}

State management of private enterprises is expressed through perspectives, tasks, and the law system promulgated by the state. Although the guidelines and laws have set out good goals, the implementation stage is decisive and directly affects private enterprises. The mechanisms and policies of the state have not solved the difficulties that private enterprises are facing while the requirements of state management of private enterprises in the market economy are it is necessary to create favorable conditions and remove obstacles and difficulties for private enterprises in accessing input and in the process of production and business activities. 


\subsection{Difficulties in Accessing Land}

The land is one of the basic and indispensable elements of the production process, but the shortage of land to use as a production ground for the private sector is now urgent. Research results from the Provincial Competitiveness Index (PCI) conducted by the Vietnam Chamber of Commerce and Industry (VCCI) show the accessibility to the land of the non-state economic sector in the period of 2009 - 2013, it was still below 7 points on average (on a 10-point scale), and the trend of improvement was very slow. The improvement trend mainly occurred in provinces with low land access index, which has narrowed the gap between the province with the highest index and the lowest one (Vu Hung Cuong, 2016). Enterprises surveyed said that their risk of land acquisition was at a record high (1.73 points, corresponding to a very high level of risk). PCI results over the previous 11 years have never recorded this indicator below 2 points. Even in the worst case, if being revoked, only $25 \%$ of businesses believe that they will be compensated satisfactorily, a sharp decrease compared to previous years $(30-40 \%)$.

Private enterprises have difficulty accessing land due to several reasons: Firstly, due to the complicated procedures for renting and transferring land, there are unclear regulations that make it difficult for investors and take a lot of time and cost. Secondly, due to unclear land planning, many areas of unused land, fallow land, land use purposes are still large, while the private sector lacks business and production ground. Thirdly, due to the small size of the enterprises' capital, it is not possible to rent land in advantageous locations because the renting land prices are high in those locations, increasing input costs.

\subsection{Difficulties in Attracting and Training Human Resources}

The private sector currently lacks qualified workers, skills, and professional skills. As a result, only low-skilled workers who need jobs, have few opportunities to choose a place to work in this area. Another reason is that while state enterprises enjoy state policies on free training of human resources, the private sector has difficulty accessing this service. Currently, our education does not pay much attention to the training according to the needs of society. In some sectors, there is a shortage of skilled cadres and workers, while there are several rampant training disciplines. The training program is still heavy in theory, little practice, slow training content, not keeping up with changes in reality so the training effectiveness is not high.

\subsection{Difficulties in Accessing Capital}

\section{- Capital from banks}

At the moment, businesses have just registered to establish capital sources mainly mobilized from the business owners themselves, relatives, friends ... Capital mobilization from credit institutions is very difficult. VCCI research shows that by the end of 2016 , only about $30 \%$ of SMEs have access to capital, the rest of about $70 \%$ of enterprises have difficulty in funding capital for production and business projects. This is because the private sector has not created the trust, so it is difficult to get loans from banks, especially medium and long-term capital. Besides, the private sector is small in scale, so the amount of loans is often small while 
transaction, investigation, and supervision costs are high.

- Access to the development assistance fund

Currently, private enterprises have access to capital from the development assistance fund. However, the amount that the private sector borrows from this fund accounts for only $8 \%$ of the fund's total lending. The reason is that the lending procedures and conditions are too tight; the legal procedures for the fund's lending conditions are still unequal between the public and private sectors, making it difficult for the private sector to borrow capital from the state's preferential capital

\subsection{Lack of Support from the Government}

\section{- Lack of a mechanism to provide business support services}

The development of service industries is promoting strong socio-economic development, including business support services. Business support services work to increase the competitiveness of businesses by delegating specialized tasks to specialized professionals. In developed countries, business support services account for at least one-third of the firm's input value. Business support services are diverse and perform different functions. The quality of service provision will greatly affect the ability of the economy to develop and compete when using this service. The reality also shows that export businesses often rely heavily on business support services from abroad to increase competitiveness in the world market, because these domestic services do not meet the quality is required.

\section{- Lack of mechanisms to create social support for the private economy}

Currently, the business environment is still unhealthy, unfair competition, there are many commercial as well as negative trade frauds caused by weak management apparatus, putting the private sector in a state of inadequacy profit. The reason is that the determination of the position and important role of the private sector is only general but there are no specific development policies and strategies, creating favorable conditions for this economic sector. Besides, the stigma and discrimination of the private sector in the management system still exist.

The legal system is still limited in regulating the economy. The lack of uniform and inconsistent legal documents has caused businesses to be in bad mood, always afraid of the changes of mechanisms and policies, so they do not dare to invest and develop production business. Besides, the regulations are complex and overlapping, making it difficult for enterprises in their production and business.

\subsection{Adjustment of State Management of Private Enterprises in the Context of World Economic Integration}

International economic integration can affect business development and state management of private enterprises in the following directions:

Firstly, opening up the integration will reduce the tariff and non-tariff barriers, putting Vietnamese private enterprises in the face of a great challenge to compete with foreign 
enterprises. This challenge is obvious, but opportunities to access international and regional markets also open. Private enterprises have not taken advantage of this opportunity because Vietnam's private enterprises are mostly small, outdated technology, weak management skills, so it is difficult to be able to compete in the domestic market and international market. To promote effective private enterprise development and enhance the competitiveness of private enterprises in the context of international economic integration, the state needs to change the way of managing, instead of "binding" enterprises with regulations, prohibitions, restrictions then switch to "serve" enterprises. Openness and international economic integration require the Government to make changes, adjustments, and innovations in state management of private enterprises so that private enterprises can develop and have enough competitiveness in the context of globalization.

Second, joining the new generation of free trade agreements, the Government will need to comply with the signed commitments. Therefore, the state management of private enterprises will also have to change by commitments. This change puts domestic private enterprises ahead of both challenges and opportunities. The challenge is that the state will no longer erect barriers to protect private enterprises; it is difficult to offer non-market support packages for businesses. In contrast, the opportunity for private enterprises is that the state will no longer discriminate between all economic sectors, will have to behave fairly among businesses and private enterprises will have a wider margin for development.

\section{Conclusion}

State management of private enterprises in the market economy in Vietnam in recent years has achieved certain achievements, as shown by the development indicators of domestic private enterprises such as in terms of the number of businesses, contribute to the economy. However, in the context of the domestic economic situation heavily influenced by external influences such as globalization, industrial revolution 4.0, ... posed new challenging requirements for the development of private enterprises and state management. Private enterprises, especially SMEs, face many difficulties in accessing land; difficulties in attracting and training human resources; accessing capital; raising technology level, and implementing digital transformation. In the new context, developing a healthy private economy under the market mechanism is an objective requirement, both urgent and long-term. It plays an important role in the process of institutional improvement and the development of a socialist-oriented market economy in Vietnam.

The State should create mechanisms, solutions, and policies to encourage and create favorable environmental conditions for the rapid and sustainable and diversified development of the private economy based on the analysis of outstanding problems in State management of private enterprises. Firstly, remove all barriers and prejudices; create favorable conditions for the development of the private economy in a healthy and right direction. Addressing difficulties faced by private enterprises in accessing financial capital, land, and labor. Second, promoting entrepreneurship movement and innovation; improve the operational efficiency of small and medium enterprises. Creating an environment and favorable conditions for associated business households to form cooperative organizations and operate under the 


\section{Al Macrothink}

Business and Management Horizons

ISSN 2326-0297

2020, Vol. 8, No. 2

enterprise model. Thirdly, encouraging the formation of multi-ownership and private economic groups to contribute capital to state-owned economic groups. Create businesses capable of participating in production networks and regional and global value chains. Finally, provide information to private enterprises about free trade agreements that Vietnam has signed, helping businesses improve operational efficiency and competitiveness in the context of world economic integration.

\section{References}

Dao, X. S., \& Vu, Q. T. (2008). "Doi moi" in Vietnam remembers and ponder. Hanoi: Knowledge Publisher.

General Statistics Office of Vietnam. (2016). Vietnam's socio-economic dynamics and situation in 5 years 2011-2015. Statistical Publishing House, Hanoi

Le, D. B. (2018). Vietnam private sector-Productivity and Prosperity. Australia Government, Mekong Business Initiative.

Pham, T. L. D. (2015). Guidelines and policies of the Party and State of Vietnam on the private economy (1986-2005), Vietnam National University Press, Hanoi

The Communist Party of Vietnam, The Central Committee of the Communist Party of Vietnam. (2016). Document of the 12th National People's Congress. Hanoi.

Tran, D. T. (2017). Vietnam Economic Report 2016-The State serves businesses. Vietnam Institute of Economics, Vietnam Academy of Social Sciences.

VCCI. (2011). Annual Business Report 2010. Theme of the year: Some trends in corporate restructuring, Information and Communications Publishing House.

Vu, H. C. (2016). Private economy A basic driver for development. Social Sciences Publishing House.

\section{Copyrights}

Copyright for this article is retained by the author(s), with first publication rights granted to the journal.

This is an open-access article distributed under the terms and conditions of the Creative Commons Attribution license (http://creativecommons.org/licenses/by/4.0/). 